\title{
気道確保困難対策ガイドラインは本当に役立つか？ 一新たなガイドラインに望むこと一
}

浅井 隆*

[要旨］「気道確保が困難な症例での気道確保法」の適切なガイドラインを策定する上での問題点と して, 気道確保困難の原因が多種多様, 換気困難の原因の多くは不明, 気道確保操作自体により気 道確保困難を引き起こし得る, 致死的誤嶼性肺炎と食道挿管が合併する, エビデンスに基づく気道 確保法が確立されていない，などがある．改善点として，気道確保困難と誤嚥が予測される場合の 適切な対処法, 覚醒下挿管時の適切な鎮静薬, 鎮痛薬の種類と投与量, “レスキュー” 器具として の声門上器具をどの時点で使うべきか, “最終手段である”経皮輪状甲状間膜力ニューラ穿刺が無 効のときにどうするか, などのより具体的な考え方を示すべきであろう.

キーワード : 気道確保, 挿管困難, 気道合併症

\section{はじめに}

全身麻酔の導入後の気道確保は，長い歴史ととも に，その方法や器具が進化し，今では“安全な”処 置として認識されている。しかし，まれながら，気 道確保困難が原因で, 致死的状況となることがあ $3^{1), 2)}$. 1990 年代の初めに, 米国の麻酔関連事故報 告の解析により，保険金請求は気道確保に関するも のが最多であることが判明した ${ }^{3)}$ 。この報告による と，気道確保に関係のある事例のうち，85\%という 高率で死亡，あるいは不可逆的な脳損傷の転帰にな つていたことが判明した ${ }^{3)}$. 一方，心停止や大出血 などの気道系以外の要因に関する事例でこのような 重篤な転帰となったのは $30 \%$ に留まっていた ${ }^{3)}$. 近 年に行われた日本での調査においても, 同様の傾向 であることが確認された ${ }^{4)}$ 。このように，まれなが ら, 起これば重篤化する危険性のある気道確保困難 *獨協医科大学越谷病院麻酔科
状態になった場合には，適切かつ迅速に対処すべき なのは明らかである。今回，気道確保困難な際の対 策法に関するガイドラインが有用であるかどうか, そして有用な場合, 既存のガイドラインで十分かど うかを検討する。

\section{Iガイドラインの役割}

そもそもガイドラインとは，オックスフォード辞 書によると，「原理原則を示すこと，あるいは示し たもの」となっている。医療現場においては，「最 低限必要とされる医療行為を示したもの」と解釈す るのが一般的であろう。

現代の医療においては, 現時点におけるエビデン スに基づき，最低限必要とされる医療行為，あるい はそれ以上の医療を供給することが要求されてい る。この要求は通常の医療に関してのみならず，肺 塞栓, アナフィラキシーショック，心肺停止など, $\begin{array}{ll}\text { 著者連絡先 } & \text { 浅井 隆 } \\ \text { T3 } 343-8555 & \text { 埼玉県越谷市南越谷 2-1-50 }\end{array}$ 獨協医科大学越谷病院麻酔科 
まれであるが，遭遇した場合に適切な処置をしなけ れば，致死的になる事象についても該当する。その ため，これらのまれな事象に対しても，最低限必要 な医療処置が何かを，すべての医師が知っておく必 要がある。

例えば，外来で注射処置中にアナフィラキシーシ ヨックが起きたとしょう。その場合，原因の除去， 人を呼ぶ，酸素の投与，アドレナリンの投与，輸液 ルートの確保, 補液の開始, 気道の確保, などを適 切かつ迅速に行う必要がある。しかし, 各臨床医が “忙しい” 臨床業務をしながら, 発生頻度の低い事 象に対する治療法のエビデンスを入手し続けるには 限界がある。そこで，ガイドラインが，今のエビデ ンスに基づいて最低限必要とされる医療行為は何か を示せば，各臨床医がまれな事象に対しても適切な 治療を迅速に行えるだろう。

\section{II 気道確保ガイドラインは必要か？}

さて，気道確保に関するガイドラインは必要であ ろうか？麻酔中の気道確保に関しては，気道確保 が困難なことはまれで，発生頻度は $0.2 〜 0.3 \%$ とさ れている。そして，気管挿管およびフェイスマスク による換気ができないと，短時間のうちに致死的と なるため, 適切かつ迅速な治療が必要となる。 上記 の理論から, 発生頻度の低い気道確保困難な事象に 対して，今のエビデンスに基づいたガイドラインが 必要，と結論づけられよう。

\section{III＼cjkstart新たなガイドラインは必要か？}

気道確保ガイドラインは欧米諸国からすでにいく つか発行されている ${ }^{5) \sim 8)}$ そそして, 米国麻酔科学会 (ASA) 発行のガイドライン ${ }^{5)}$ は, 数年ごとに改訂が され，今のエビデンスに基づいたものとなる。

では，日本の臨床医はこれら既存のガイドライン を用いればよいのだろうか？ 答えからすると，不 十分と言わざるを得ない。

他領域のガイドラインとして，心肺蘇生法に関す
るものが，米国心臟協会 (American Heart Association)功発行されている。このうち，医療従事者 用の二次救命処置(Advanced Cardiovascular Life Support: ACLS) ガイドラインは広く取り入れられ， 心肺停止への心肺蘇生時に，日本を含め世界中でほ ぼ同じ方法で治療が行われている。では，既存の気 道確保法ガイドラインはどうであろうか？ 心肺蘇 生法と違い，日本では十分に浸透していないのが現 状であろう。その原因は，さまざまあり得るが，ま ず次の症例 ${ }^{9)}$ の気道確保法について考えると理解で きると思われる。

$<$ 症例 $1>$

30 歳の女性．妊娠 38 週，前置胎盤および妊娠中 毒症のため入院していた。昼食後に大量出血したた め, 緊急帝王切開術のため手術室に搬送されてきた。 血圧が $72 / 24 \mathrm{mmHg}$ であったため，覚醒下の気管挿 管を試みたが，妊婦があばれて不可能であった。輪 状軟骨部圧迫下にサイアミラールとサクシニルコリ ンを用いて全身麻酔を急速導入し，喉頭鏡を挿入し たが，咽頭および喉頭浮腫があり，声門が確認でき なかった。 3 度目の喉頭展開でからうじて披裂軟骨 が見え，挿管した。

直ちに手術を開始し，人工呼吸を試みたが，ここ で初めて食道抻管になっていることが判明した。千 ューブを抜去し，マスク換気を試みたが不可能で, ヘモグロビン酸素飽和度 $\left(\mathrm{SpO}_{2}\right)$ が $80 \%$ 以下となり， 不整脈が発生し始めた。その数分後に胎児は仮死状 態で娩出され，その後すぐに母体は自発呼吸をし始 めた。低酸素血症が改善したため，再度喉頭展開を 試みたところ突然嘔吐し，誤與した。

この症例の気道確保のどこが不適切であったの か，またどのような適切な対処をすべきであったの か，おそらく誰も明確な解答を出せないであろう。 事実，今あるガイドラインからは，この症例での適 切な気道確保法は何か，についての明確な方策を得 ることはできない.

ではなぜ既存のガイドラインは不十分なのであろ 
うか？その理由は, 心肺停止や肺塞栓に対するガ イドラインとは違い, 次のような複数の問題点があ るからであろう。

\section{1. 気道確保困難の原因が多種多様である.}

気管扦管あるいはマスク換気が困難となる原因は 多種多様であることが知られている。そして，さま ざまな原因に対する対処法もそれぞれ違う。このよ うに，対処法は複数あるが，ガイドラインでそれら を示すことは困難である。

\section{2. 換気困難の原因の多くは不明である.}

フェイスマスクを用いた陽圧換気が困難となった 場合, 原因の多くは不明である。そのため, 適切な 対処法の決定も困難となる。

3. マスク換気が困難な場合, 困難さの程度はさまざま あり, マスク換気の困難さの程度の差により, 適切 な対処法にも違いがある.

マスク換気が困難な場合, 困難な程度は症例によ り違いがあり，換気量が少ない場合から，まったく 換気が不可能な場合がある。また, 酸素予備能と消 費量の違いにより，低酸素血症になるまでの時間も 症例により違う。そのため, 対処法と緊急度に違い が出る。しかし，どの程度のマスク換気困難な時点 で声門上器具や観血的気道確保(輪状甲状間膜穿刺, 気管切開)を施行すべきなのかを決めるのに十分な エビデンスは存在していない.

\section{4. 麻酔の導入, 気道確保の操作自体により気道確保困}

\section{難を引き起こし得る.}

気道確保が困難と予測されている場合, 覚醒下に 気管支ファイバースコープなどを用いて “より安 全”に気道確保をするのがよいとされている。しか し, 気道確保が困難な症例で行う麻酔や気道確保法 自体により，気道確保がさらに困難となってしまう ことがある。次の例を見ればそのことが明らかであ ろう。

$<$ 症例 $2>$

56 歳の女性. $154 \mathrm{~cm}, 46 \mathrm{~kg}$. 頸椎固定術が予定 された。関節リウマチに罹患しており, ステロイド
を内服していた，手足は拘縮し，頭頸部も極度に前 屈固定していた.気管抻管が困難と予測されたため, 鎮静下の気管支ファイバースコープを用いた気管挿 管を予定した。

手術室において, 鎮静と気道の局所麻酔を施行し た後，気管支ファイバースコープの挿入を試みた。 声門の確認は極めて困難であったが，浮腫状態で狭 窄している声門を確認することができた。気管支フ アイバースコープを気管に挿入した後，気管チュー ブを進めようとしたが抵抗があった。この時点で患 者は激しく咳き込み，シーソー呼吸状態となった。 気管支ファイバースコープを抜去し，酸素を投与し て自発呼吸を促したが，気道は閉塞した状態で，マ スク換気も不可能であったため，低酸素血症となっ た。緊急気管切開が施行された。

この例を見れば明らかなように，どの場合に処置 を避けるべきかが不明瞭である。

\section{5. 致死的誤嘸性肺炎と食道挿管は挿管困難な場合に高 頻度に起こる.}

気道確保が困難な場合，気管挿管あるいは換気困 難による低酸素状態が問題となるだけではない。気 道確保が困難な場合，誤嚥と気づかれない食道誤挿 入が併発する率が高いことが判明している。そのた め，酸素化困難の解消のみならず，致死的誤嚥と食 道䛊挿管の複合的問題を阻止する対処を同時に行う 必要がある.

\section{6. エビデンスに基づく気道確保法が確立されていない.}

現在, さまざまな気道確保法が考案され, さまざ まな気道確保器具が発売されているが, どの方法を 用い，どの器具を選択するかを決めるだけのエビデ ンスが十分にないと言わざるを得ない。そして，各 地域, 各施設, 各臨床医により, “好み”や “得手, 不得手”があり，それらに基づいて選択されている のが現状である．例えば，通常の喉頭鏡を用いて気 管挿管が困難な場合，日本ではスタイレットが補助 具として第 1 選択となっているが，英国圈ではガム エラスティックブジーが第 1 選択となっている。そ 
してこれらの性能比較をした研究はほとんどなく， エビデンスに基づく方策を立てにくいのが現状であ る.

7. 適切な器具と処置法であっても, それらを施行する のは非現実的であったり，高い技術を要したりする ことがある.

既存のガイドラインでは，気管挿管およびマスク 換気が不可能となり，低酸素血症になった場合，声 門上器具を挿入し, それも無効の場合, 観血的気道 確保をする，となっている。しかし，低酸素血症と なってから，経皮輪状甲状間膜穿刺などの観血的気 道確保を施行したことがある麻酔科医は極めて少な く, また必要な器具がすぐに使える環境になってい ない施設も少なからずある。また日本では, 通常の 全身麻酔中の声門上器具の使用頻度は西欧諸国に比 べ低いのが現状であろう。そのため，換気困難で低 酸素血症状態となった時点で, 声門上器具および観 血的気管扦管器具が “レスキュー”として問題を 解決できる頻度は相当低いと考えられる。

\section{IV＼cjkstart新たなガイドラインに必要なこと}

上記のさまざまな問題があるにも関わらず，なぜ ガイドラインが必要なのであろうか？ それは，頻 度がまれで，各症例で対処法が一定でなく，選択を 誤ると致死的になり得る事例においては，各臨床医 の経験則に基づく判断のみでは最低限の医療水準を 満たし得ない可能性が高いから，と言えよう。

新たなガイドラインが含むべき項目は次の通りと 思われる。

1. 気道確保困難が予測される場合に, どのように適切 な気道確保法を選択すべきかについて示すべき.

既存のガイドラインのほとんどすべては, 換気困 難, 挿管困難になってからの対処法が示されており, 気道確保困難が予測される場合に，どのように適切 な気道確保法を選択すべきかについて，まったく， あるいはほとんど言及されていない.

換気困難になった場合の対処法は確立されていな
いため，どのような方策で “挿管不可，換気不可” 状態にならないようにするかが重要である。ガイド ラインではその予防法についてさらに詳しく示すべ きであろう。

\section{2. 覚醒下挿管を選択した場合の適切な鎮静薬，鎮痛薬} の種類と投与量を示すべき.

覚醒下挿管を試みても気道閉塞の危険性がある。 しかし，実際には各臨床医の経験則のみで，局所麻 酔薬，鎮静薬，鎮痛薬の種類と量を決めているのが 現状である。

新たなガイドラインは，今のエビデンスでは代表 的などの薬が “より安全”で，どの量程度なら気道 合併症を起こしにくいか，を示すべきであろう。

\section{3. 誤舆の危険性がある症例での適切な気道確保法の流} れを示すべき.

誤與は低酸素血症以上の頻度で全身麻酔に関する 死亡の原因となっている。そして，気道確保法の違 いにより, 誤嚥を誘発する頻度も違う可能性がある。

新たなガイドラインでは，䛊嚥をできるだけ誘発 させず，また防止する気道確保法を示すべきであろ う。例えば，挿管困難が予測されている症例では， 迅速導入を避けるべき，との記載が必要であろう。

4. ラリンジアルマスクを代表とする声門上器具は, マ スク換気困難なときの“レスキュー”器具としての 役割があるとされているが，それをどの時点で使う かをより明確に示すべき.

マスク換気が困難な場合に，声門上器具が “レス キュー”として役立つ可能性がある。しかし，マ スク換気は困難であるが急速な低酸素血症になって いない場合，不用意に声門上器具を挿入することに より，気道の閉塞を悪化させる危険性がある。その ため，例えば，マスク換気が不能で観血的気道確保 をする準備をしている間以外の夕イミングで声門上 器具を挿入すると状態が悪化する危険性がある，な どの，より明確な考え方を示すべきであろう。 
5. “最終手段である” 経皮輪状甲状間膜カニューラ穿 刺による換気は必ずしも有用でない可能性があると 示すべきである.

“最終手段である”経皮輪状甲状間膜カニューラ 穿刺による換気の成功率は低い可能性があることが 判明した ${ }^{1)}$.そのため, ガイドラインで挙げられた 管理法が必ずしも有用でない可能性があることを示 し, その場合のさらなる対処法, 例えば耳鼻咽喉科 医による外科的気管切開などを緊急に依頼するのが

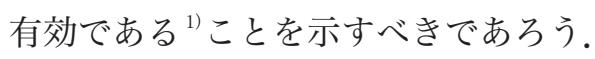

\section{結語}

気道確保困難に対するガイドラインは，まれなが ら重篤な合併症を防止する, あるいは起こったとき に迅速かつ適切に対処する上で役立つと判断でき る.しかし, 現在出されているガイドラインの多く は改訂されておらず，また改訂されているものも， 臨床にまだ十分に役立つものとは言えない. 今後, ガイドラインは医学の進歩とともに常に改訂し, 日々の臨床を行っている麻酔科医に役立つように， さらに具体的な考え方を示すべきであろう。

追記本論文は, 日本臨床麻酔学会第 33 回大会 (2013, 金沢)におけるシンポジウム (7)「日本版DAM アルゴリズム」において発表した「気道確保困難対 策ガイドラインは本当に役立つか？」での講演を基 に作成した。 その後, 日本麻酔科学会が気道確保に 関するガイドラインを出版した ${ }^{10}$. このガイドライ ンでは本論文での提案が多く取り入れられており, 日本のみならず，世界中で有用なガイドラインとな
っていると言えよう。

\section{参考文献}

1) Cook TM, Woodall N, Frerk $C$ : Major complications of airway management in the UK : results of the Fourth National Audit Project of the Royal College of Anaesthetists and the Difficult Airway Society. Part 1: Anaesthesia. Br J Anaesth 106 : 617-631, 2011

2) Norris AM, Hardman JG, Asai $T: A$ firm foundation for progress in airway management. Br J Anaesth $106: 613-616,2011$

3) Caplan RA, Posner KL, Ward RJ, et al. : Adverse respiratory events in anesthesia : a closed claims analysis. Anesthesiology $72: 828-833,1990$

4）入田和男, 川島康男, 嚴康秀ほか:「麻酔関連偶発症例 調查2002」㧍よび「麻酔関連偶発症例調查 1999-2002」 について: 総論一(社) 日本麻酔科学会安全委員会偶発 症例調查専門部会報告一. 麻酔 $53: 320-335,2004$

5) Practice guidelines for management of the difficult airway : an updated report by the American Society of Anesthesiologists Task Force on Management of the Difficult Airway. Anesthesiology 118 : 251-270, 2013

6) Henderson JJ, Popat MT, Latto IP, et al. : Difficult Airway Society guidelines for management of the unanticipated difficult intubation. Anaesthesia $59: 675-694$, 2004

7) Crosby ET, Cooper RM, Douglas MJ, et al. : The unanticipated difficult airway with recommendations for management. Can J Anaesth $45: 757-776,1998$

8) Petrini F, Accorsi A, Adrario E, et al. : Recommendations for airway control and difficult airway management. Minerva Anestesiol $71: 617-657,2005$

9）浅井隆：挿管困難症およびCICVに対するアプローチ： 成人編. 麻酔 $55: 13-23,2006$

10) Japanese Society of Anesthesiologists : JSA airway management guideline $2014:$ to improve the safety of induction of anesthesia. J Anesth $28: 482-493,2014$ 


\title{
Are Current Guidelines about Difficult Airway Management Truly Useful? : What Factors Should Be Included to New Guidelines
}

\author{
Takashi ASAI \\ Department of Anesthesiology, Dokkyo Medical University
}

The currently available guidelines about difficult airway management are not ideal. New guidelines are needed, but some practical difficulties remain for the following reasons : the cause of difficult intubation or difficult ventilation are numerous ; difficult mask ventilation occurs without apparent reason ; difficult airway management in itself may produce airway obstruction ; and difficult airways are associated with another two major life-threatening complications (pulmonary aspiration and unnoticed esophageal intubation). Nevertheless, new guidelines could be made more useful by incorporating the following factors: structured methods to plan airway management in patients with predicted difficult airways ; types and doses of analgesics and sedatives for "awake intubation" ; a clearer indication of when a supraglottic airway should not be used as a rescue; and what the next plan should be when percutaneous cricothyroidotomy fails.

Key Words : Airway management, Difficult intubation, Airway complications

The Journal of Japan Society for Clinical Anesthesia Vol.35 No.3, 2015 